\title{
Komodifikasi Seks Ala Majalah Hai: Safe Sex, Safe Positioning
}

\author{
Muria Endah Sokowati \\ Departemen Ilmu Komunikasi, Universitas Muhammadiyah Yogyakarta \\ Email: muriaendah@umy.ac.id/Hp: 08164267335
}

\begin{abstract}
Adolescence as apolitical and uncritical social category becomes the object of socialization and education about morality from adult. The social institution, including media subjugated their desire in the name of sex education. Hai magazine displays sexual content to give sex education to adolescence. Instead of educating sex through its articles and rubrics, Hai made sex as selling material. Hai produced the discourse of safe and healthy sex as the strategy to safe its positioning in the media industry competition. This writing revealed how sex education in teen magazine doesn't only fulfill the adolescence's needs of sexual information, but also becomes commodity to attract the readers'attention.
\end{abstract}

Keywords: Sexuality, Comodification, Adolescence, Media

\begin{abstract}
Abstrak
Remaja sebagai kategori sosial apolitis dan tidak kritis menjadi objek sosialisasi dan edukasi soal moralitas oleh orang dewasa. Penundukan hasrat atas nama pendidikan seks dilakukan berbagai institusi sosial, termasuk media. Majalah Hai menampilkan konten seks untuk tujuan edukasi seks pada remaja. Alih-alih menyampaikan materi seks secara edukatif, Hai justru menjadikan seks sebagai materi yang menjual. Hai memproduksi wacana seks yang sehat dan aman dalam rubrik dan artikel sebagai strategi untuk mengamankan posisinya di tengah persaingan industri media. Tulisan ini mengungkap bagaimana pendidikan seks di majalah remaja tidak semata memenuhi kebutuhan informasi seks remaja, namun menjadi komoditas untuk menarik perhatian pembaca.
\end{abstract}

Kata Kunci: Seksualitas, Komodifikasi, Remaja, Media

\section{Pendahuluan}

Di tengah-tengah berlakunya paham neoliberalisme di Indonesia, tidak ada bidang kehidupan yang tidak bisa dijadikan komoditas. Seks merupakan salah satu topik yang memiliki daya jual. Potensi seks sebagai materi yang menjual telah dijelaskan oleh para tokoh di bidang pemasaran. Menurut Kent Wertime
(2002:100) seks merupakan cara efektif dalam merangkul konsumen. Materi seks, dirasa efektif dalam menarik dan mempertahankan perhatian, meningkatkan ingatan, dan membangkitkan hasrat konsumen (Shimp, 2003:481). Atas dasar itulah konten seks dimanfaatkan dalam promosi produk atau produk yang dijual pada konsumen. Media memasukkan unsur seks sebagai bagian 
dari materi yang dijual. Akhirnya seks menjadi komoditas. Inilah komodifikasi seks.

Komodifikasi menurut Mosco (2009:127) merupakan proses transformasi atas sesuatu yang dianggap bernilai untuk dijadikan produk yang dapat dijual. Proses tersebut merupakan cara kapitalisme melancarkan tujuannya untuk mengakumulasi modal dengan mentransformasikan nilai guna menjadi nilai tukar. Industri media menjadi salah satu institusi yang menjalankan produksi dan distribusi pesan dalam rangka akumulasi modal dengan menggunakan logika komodifikasi.

Seks untuk kepentingan komodifikasi di media menimbulkan eksploitasi informasi dengan tujuan menaikkan oplah dan meningkatkan ketergantungan khalayak pada nilai-nilai yang ditetapkan media. Konten majalah Playboy misalnya, adalah komodifikasi kebebasan seks yang mengeksploitasi tubuh perempuan. Kesuksesan majalah ini melahirkan diskursus seksualitas, menciptakan tren gaya hidup dan kehidupan seksual yang diadopsi media lainnya (Anugrah, 2014).

Komodifikasi seks oleh media cetak di Indonesia mulai marak pada akhir tahun 1990an. Kondisi ini didorong oleh euforia kebebasan pers pasca runtuhnya Suharto. Presiden Habibie membawa Indonesia pada iklim yang demokratis dengan melakukan liberalisasi media di tahun 1999 yang melepaskan kontrol negara atas media.

Kondisi ini mengalihkan kontrol negara atas media kepada kekuatan bisnis. Media telah beralih dari ruang kuasa negara menuju ruang kompetisi pasar. Media tidak lagi menjalankan kebijakan negara, namun berorientasi pada pemilik modal yang menggerakkan aktivitas media pada komersialisasi. Media berada di tengah kompetisi pasar untuk menghasilkan profit yang besar dan menggeser muatannya pada konten hiburan yang lebih menjual. Semua dilakukan untuk mendukung sistem ekonomi media. Konten media yang mendiskusikan seksualitas adalah program hiburan yang disukai khalayak.
Konten hiburan dengan materi penuh sensasi dan kontroversi menjadi pilihan. Dalam industri media cetak, muncul jurnalisme kuning. Kehadiran surat kabar dan tabloid sejenis harian Pos Kota dan Lampu Merah membanjir. Mediamedia tersebut berisi berita sensasional disertai visualisasi yang mengeksploitasi tubuh dan sensualitas perempuan.

Komodifikasi seksualitas dalam media cetak menjadi-jadi ketika industrialisasi media memunculkan media franchise tahun 2000an. Akibatnya, majalah-majalah asing seperti Men's Health, Esquire, FHM, Maxim hingga Playboy terbitan Indonesia mudah ditemukan. Pembaca menjadi terbiasa melihat selebriti dan tren asing, sehingga gaya hidupnya merujuk pada budaya asing, atau barat dalam hal ini.

Tren ini diikuti oleh munculnya majalah lokal yang memasang selebriti asing baik di sampul maupun halaman utamanya serta memuat artikel dengan nuansa budaya pop barat. Majalah-majalah tersebut menampilkan topik-topik seksualitas dengan cukup terbuka. Misalnya dengan judul berikut: "Pria Tanpa Perkawinan: Sex Yes, Marriage No!" (Male Emporium, Januari 2005), "Panduan 12 Gaya Bercinta ala Tao" (Popular, Februari 2006), "Stamina Seksual: 10 Tips Bertahan Lebih Lama dalam Seks" (FHM, Maret 2007), atau "Sex and Profession" (Maxim, Januari 2007).

Seksualitas selalu menarik diperbincangkan. Tidah hanya untuk laki-laki dewasa, namun juga laki-laki berusia remaja. Seksualitas justru menarik perhatian remaja yang sedang dalam proses pencarian identitas. Tak adanya diskusi terbuka tentang seksualitas mengakibatkan remaja mencari informasi dari berbagai sumber, seperti majalah.

Konten seksualitas menjadi tema kontroversial karena dianggap mengancam moralitas sehingga tabu dibahas. Akibatnya, tema-tema seks justru membangkitkan rasa ingin tahu yang besar bagi remaja. Sebagai institusi media komersial, majalah Hai tidak melepaskan peluang itu. Hai berupaya memuaskan rasa ingin tahu pembaca yang berusia remaja. Menawarkan 
konten seksualitas sebagai komoditas bagi remaja menjadi strategi Hai untuk mempertahankan pangsa pasar, bahkan merangkul pembaca baru.

Dengan target pembaca laki-laki berusia remaja, tentu saja mustahil bagi Hai menampilkan foto perempuan berpakaian minim atau menuturkan secara gamblang skandal seks layaknya majalah Cosmopolitan, For Him Magazine, atau Popular yang mengumbar ceritacerita seks maupun gambar-gambar perempuan atau pasangan laki-laki dan perempuan dengan pose-pose erotis. Memperbincangkan seks kepada remaja agar tidak menimbulkan polemik dilakukan lewat pendidikan seks. Pendidikan seks penting bagi remaja karena di usia remaja merupakan masa di mana organorgan seksualnya mulai berkembang. Akibatnya remaja sudah memiliki hasrat seksual. Padahal menurut seksualitas prokreatif hubungan seksual hanya dapat dilakukan oleh pasangan laki-laki dan perempuan yang sudah menikah.

Walaupun mengatasnamakan pendidikan seks, dengan materi seks yang edukatif, tidak dipungkiri bahwa konten seks justru memberikan hiburan bagi pembaca. Fungsi menghibur menjadi fungsi wajib bagi media di era liberalisasi dan industrialisasi menggeser fungsi informatif dan edukatif. Fungsi menghibur konten seks ditampilkan lewat gaya bahasa yang humoris atau istilah-istilah populer remaja. Selain itu artikel dan rubrik seksualitas disajikan dengan model lay-out halaman yang bervariasi. Ilustrasi juga bervariasi, mulai foto, lukisan atau gambar komikal dengan cerita humor.

Rubrik dan artikel seksualitas menjadi sarana bagi Hai untuk memberikan materi yang berkaitan dengan seksualitas secara edukatif sekaligus menghibur bagi pembacanya. Lewat fungsi hiburan inilah majalah Hai menarik minat dan perhatian pembaca sehingga berpotensi meraup keuntungan. Berdasarkan latar belakang tersebut, maka tulisan ini akan memaparkan lebih lanjut bagaimana majalah Hai melakukan komodifikasi seks lewat promosi seks aman dan sehat.

\section{Metode Penelitian}

Tulisan ini didasarkan pada sejumlah cara pengumpulan data. Pertama, dengan melakukan pengumpulan data terhadap konten majalah Hai dari periode waktu tahun 1999-sampai 2004. Penulis mencermati dan menganalisis isi dari majalah Hai yang berisi tentang pendidikan Seks bagi remaja selama penerbitan tersebut. Kedua, penulis melakukan pengamatan terhadap berbagai situasi yang mendasari terjadi dan adanya kompetisi media yang memicu terjadinya komodifikasi konten media.

Data-data tersebut diolah, dikelompokkan dan disistematisir berdasarkan pijakan analisis yang digunakan. Pendekatan tulisan ini merupakan pendekatan yang berkaitan dengan ekonomi politik media yang berkenaan dengan komodifikasi konten media untuk tujuan ekonomi politik media. Sajian data penelitian dikembangkan berdasarkan temuan terhadap proses pengumpulan dan pengolahan data yang mencakup deskripsi terhadap objek penelitian dan kecenderungan isi atas komodifikasi terhadap pendidikan seks bagi remaja pada majalah Hai.

Deskripsi terhadap objek penelitian memberi gambaran terhadap kondisi faktual terhadap objek yang dikaji baik secara kelembagaan atau secara profesional. Sedangkan kecenderungan isi digunakan untuk menunjukkan adanya komodifikasi terhadap isi teks atau konten media. Peneliti melakukan analisis isi majalah Hai untuk melihat perbandingan antara konten iklan dan konten lainnya pada tahun 1991 sebagai masa sepinya minat pengiklan di majalah Hai, dengan periode 1995-2004. Sampel yang dipilih adalah majalah edisi khusus seks, disesuaikan dengan asumsi bahwa konten seks menarik minat pengiklan

\section{Hasil dan Pembahasan \\ Rubrik Seksualitas Majalah $\mathbf{H a i}$}

Majalah Hai adalah satu-satunya majalah remaja laki-laki yang pernah ada di Indonesia, terbit sejak Januari 1977 dan hingga kini masih tetap eksis serta berada di bawah perusahaan PT 
Kompas Gtamedia yang bergerak di bidang media massa. Majalah Hai merupakan kepanjangan dari Hibur, Asuh, Ilmu.

Menurut Danie Satrio (wawancara, 2014), pemimpin redaksi, Hai muncul untuk ikut meramaikan pasar majalah remaja pada masa itu. Semua majalah remaja yang ada ditujukan untuk remaja perempuan. Berbeda dengan majalah remaja lain yang feminin, Hai justru hadir dengan konten maskulin. Misalnya komik, artikel militer atau otomotif, atau artikel musik bergenre keras. Kehadiran Hai pada saat itu mengisi kekosongan majalah bertema maskulin dan melihat adanya potensi pasar untuk itu.

Majalah remaja laki-laki menjadi strategi diferensiasi Hai dengan majalah remaja lainnya. Hal tersebut tercermin dalam tagline "cermin kehidupan remaja pria" yang menegaskan majalah Hai-seperti halnya cermin-menjadi refleksi apa dan bagaimana menjadi remaja lakilaki. Majalah Hai menjadi referensi bagi remaja laki-laki dalam membentuk identitasnya.

Konten seksualitas dalam majalah Hai dimulai tahun 1990an, dilatarbelakangi banyaknya pertanyaan eksplisit tentang seksualitas dari pembaca lewat telepon. Menurut Danie Satrio, pembaca memiliki rasa ingin tahu yang cukup besar tentang seksualitas, namun kesulitan mendiskusikannya dengan orang tua atau guru. Melihat potensi seks sebagai daya tarik bagi remaja, maka pada tahun 1999 Hai mulai membuat rubrik yang membahas problem seksualitas dan berfungsi sebagai pendidikan seks bagi remaja.

Tema-tema seksualitas yang dibahas cukup bervariasi, seperti mimpi basah, masturbasi, permasalahan seputar penis, fantasi, homoseksual, seks bebas, pornografi, cyberseks, penyakit menular seksual, penyimpangan seksual dan lain-lain. Tema-tema tersebut ditampilkan dalam beberapa format: artikel liputan tentang seksualitas, tanya jawab, artikel lepas tentang tema tertentu, opini selebritis atau tokoh, tulisan pakar, tips-tips, artikel tentang mitos seks, rubrik seks, kuis yang berfungsi sebagai indikator perilaku remaja yang berkaitan dengan persoalan seks, atau polling redaksi tentang tema seksual tertentu.

Pembahasan dilakukan secara informatif dan edukatif oleh berbegai narasumber, seperti dokter, psikolog, sosiolog, seksolog, rohaniwan atau guru. Redaksi juga mengambil sumber dari internet, seperti: www.teengrowth.com atau Onhealth.com. Data artikel dan rubrik seksualitas tahun 1995-2004 seperti pada diagram 1. Tulisan seksualitas cukup minim tahun 1995 dan 1996 dan terus berkurang tahun 1997 dan 1998. Namun mulai tahun 1999 jumlahnya meningkat drastis, dan jumlahnya stabil di tahun-tahun berikutnya. Lonjakan ini terjadi bersamaan dengan liberalisasi dan industrialisasi media yang membawa euforia kebebasan pers dan

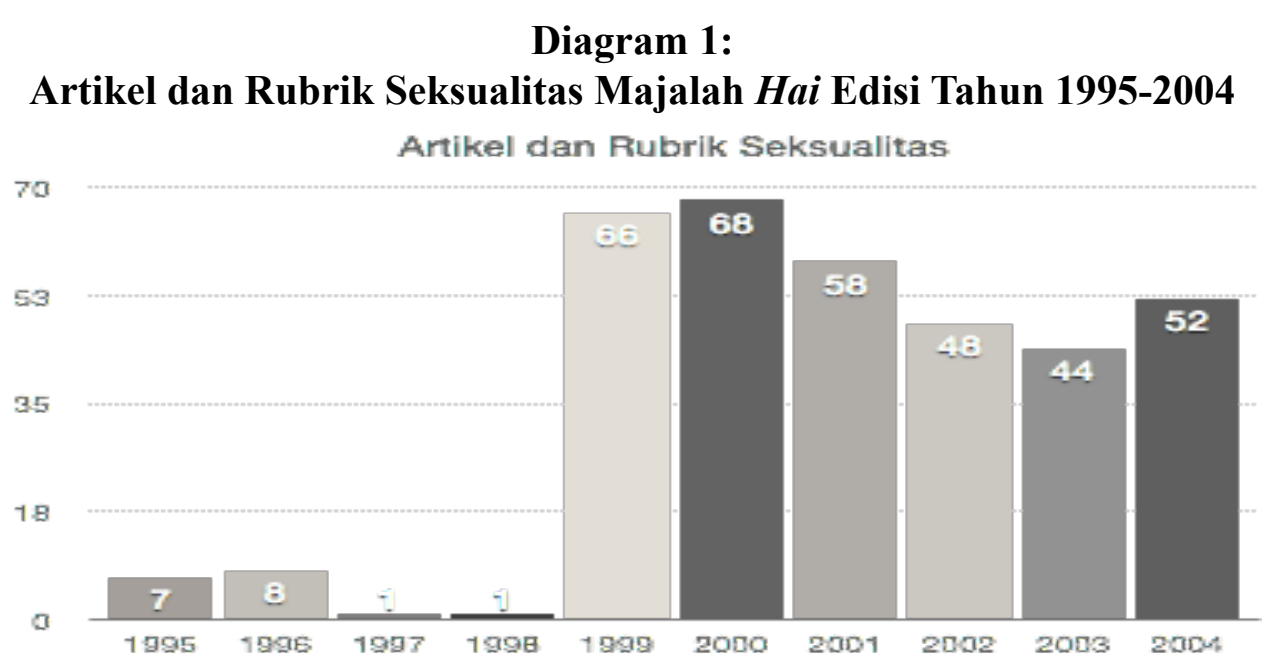

Sumber: Diolah dari Majalah Hai yang terbit pada tahun 1995-2004 
komodifikasi seks di media. Maraknya konten seks menjadi bagian dari semangat liberalisasi dan industrialisasi majalah Hai. Konten seks adalah upaya komersialisasi yang dilakukan Hai.

\section{Diskursus Kenikmatan Untuk Promosi Seks Yang Aman}

Hai menggambarkan seks yang nikmat dan ditunjukkan lewat ilustrasi berikut: seksual didefinisikan Hai sebagai perilaku akibat dorongan seksual. Mulai bergandengan tangan, berpelukan, bercumbu, sampai berhubungan seks dengan kelamin (Hai, 2/4/2001).

Dalam majalah Hai dijelaskan, seks yang aman adalah perilaku seksual yang sehat secara fisik, psikis, maupun sosial; dilakukan dengan bertanggung jawab, dilandasi cinta, normal

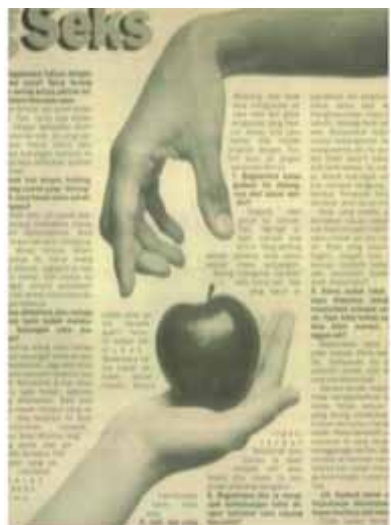

Gambar 1

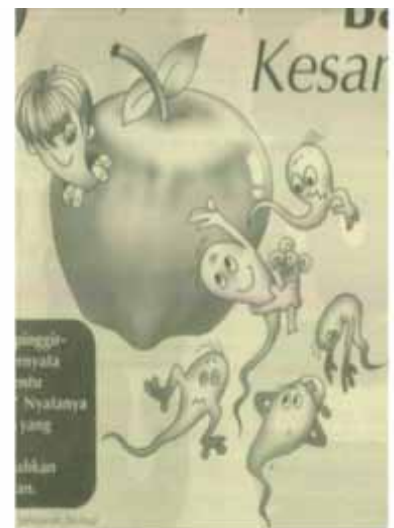

Gambar 2

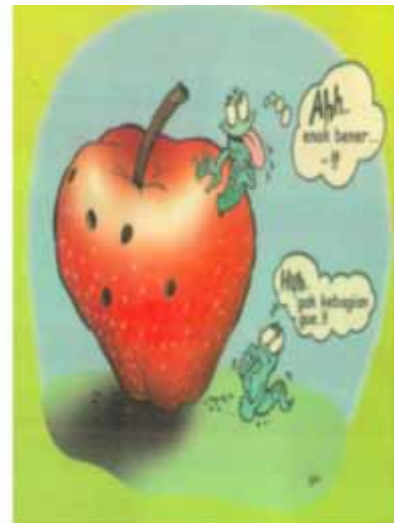

Gambar 3
Gambar 1 terdapat dalam artikel "Lebih Tahu Tentang Seks?" terlihat foto tangan perempuan yang menawarkan buah apel ranum kepada tangan laki-laki sebagai metafora perempuan yang menawarkan kenikmatan pada laki-laki. Gambar 2 dalam artikel "Perjalanan Sperma: Banyak Kesandung Mitos", menampilkan beberapa makhluk yang mengacu pada sperma sedang mengelilingi buah apel. Satu makhluk ada di dalam buah apel dan tersenyum, menunjukkan nikmatnya berada di dalam apel. Gambar 3 dalam artikel "Ukuran Keperjakaan: Asal Jangan Main-Main Dengan Alat Kelamin", mengilustrasikan hal yang sama, bahkan makhluk dalam gambar itu menegaskan kenikmatannya berada di dalam buah apel dan berkata, "Ahh...enak bener..!!!" Apel adalah simbol seks yang nikmat. Buah apel merah adalah lambang kenikmatan.

Dalam beberapa artikel dan rubrik seksualitas yang dimuat selama tahun 19952004, Hai menjelaskan beberapa perilaku seksual yang dikategorikan sebagai perilaku seksual yang aman dan tidak aman. Perilaku atau tidak melawan norma yang berlaku, dan sakral. Perilaku seks tidak aman adalah perilaku seks yang tidak sehat, abnormal dan berdosa bagi pelakunya. Perilaku seks dianggap tidak aman jika dilakukan tanpa tanggung jawab, berdasarkan nafsu, atau sebagai pelarian atas pengalaman buruk masa lalu. Kenikmatan seksual adalah kenikmatan yang diperoleh dari seks yang aman.

Hai telah membuat konstruksi tentang kenikmatan seksual. Hai menjelaskan bahwa kenikmatan seksual diperoleh lewat seks yang aman. Semakin aman perilaku seksual, maka semakin besar kemungkinan untuk memperoleh kenikmatan seksual. Membangun diskursus kenikmatan dalam kerangka seks yang aman menunjukkan dukungan Hai terhadap seksualitas yang normatif. Membicarakan kenikmatan seksual membuat Hai seolah-olah mendukung liberalisme seksual yang berorientasi pada kenikmatan seksual. Namun kenikmatan seksual yang dijelaskan oleh Hai adalah kenikmatan yang mendukung seksualitas yang normatif dan konservatif. Hal ini menunjukkan ambivalensi 
Hai dalam memproduksi wacana seksualitas.

\section{Komodifikasi Seks}

Pembahasan seks di majalah Hai merupakan upaya komodifikasi. Daya tarik seks menjadi komoditas yang dibungkus oleh pendidikan seks. Iqani (2012:120) menjelaskan bahwa seks di media bukan sekedar penjelasan tentang hasrat. Namun seks menjadi moda komunikasi yang menjanjikan kesenangan bagi yang mengkonsumsinya. Kata "seks" atau "sex" menjadi daya tarik dan mendorong rasa ingin tahu khalayak bahwa informasi di dalamnya akan memuaskan hasrat seksual secara verbal dan visual. Akibatnya, sampul dan headline sering menyisipkan kata itu.

Tidak cukup tulisan, visualisasi model dengan penampilan menggoda menjadi contoh bagaimana media menjual seks. Hai menggunakan strategi tersebut dalam sampul yang menampilkan seks sebagai materi yang dijual. Contohnya sampul majalah Hai edisi seks berikut:
Kata "sex" diekspos dengan tulisan yang cukup besar dan warna menyolok. Model perempuan ditampilkan dengan pose menggoda. Misalnya penampilan Lola Amalia sebagai bintang sampul edisi tahun 2000. Dengan fokus pada wajah, ia tampil seolah-olah tanpa busana. Begitu juga bintang sampul di edisi 2001 dan 2002, Dina Olivia dan Marcela Zalianty, seorang model terkenal pada masa itu tampil dengan busana yang terbuka, di bagian atas pada edisi 2001 dan bagian bawah di edisi 2002 .

Untuk edisi 2003, walaupun berbusana tertutup, pose Sigi Wimala yang menggigit bibir adalah pose menggoda. Edisi 1999 dan 2004 agak berbeda karena menghadirkan laki-laki sebagai sampul. Di edisi 2004, sang model membuka celananya sambil membelakangi kamera. Dengan menampilkan sampul majalah yang mengandung daya tarik seksual menjadi indikasi bahwa materi seks adalah topik yang dijual untuk menarik perhatian pembaca. Mengutip Reichert (2006), daya tarik seksual mampu memberikan pengalaman melihat (viewing

\section{Gambar 4}

\section{Sampul Hai Edisi Seks 1999-2004}
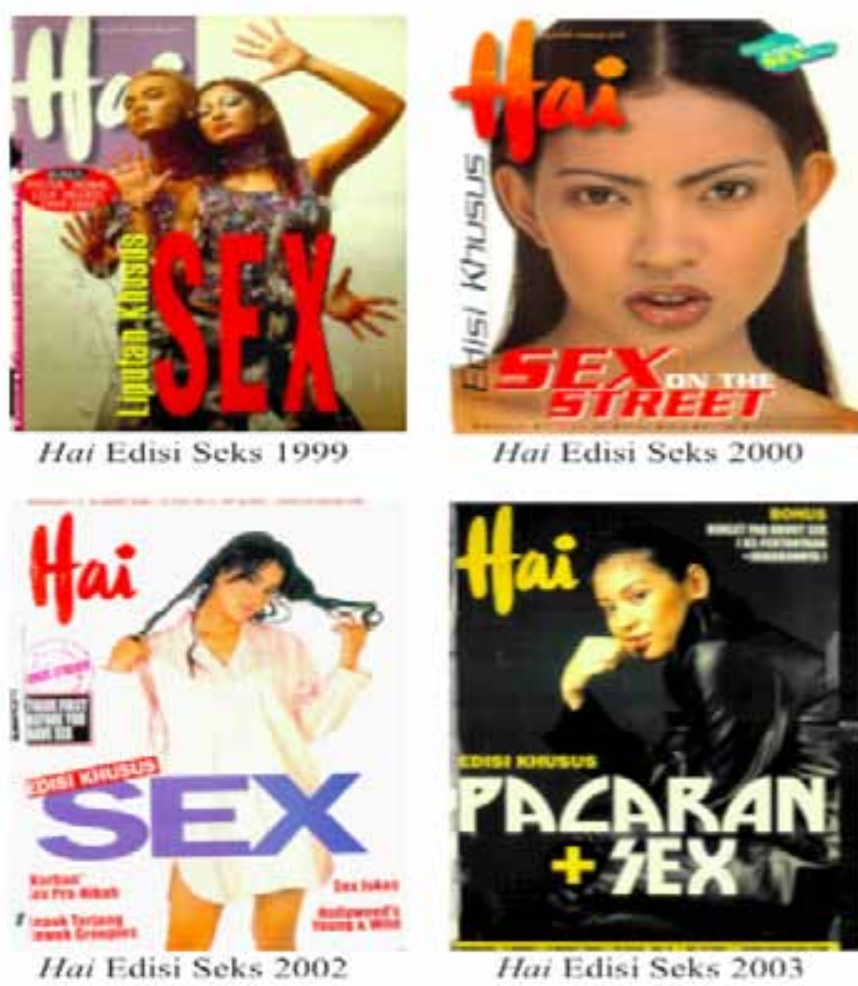

Hai Edisi Scks 2000

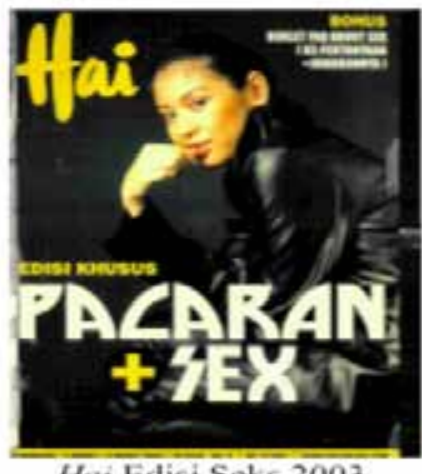

Hai Edisi Seks 2003

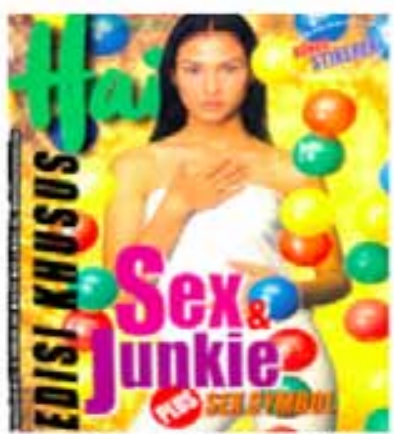

Hai Edisi Seks 2001

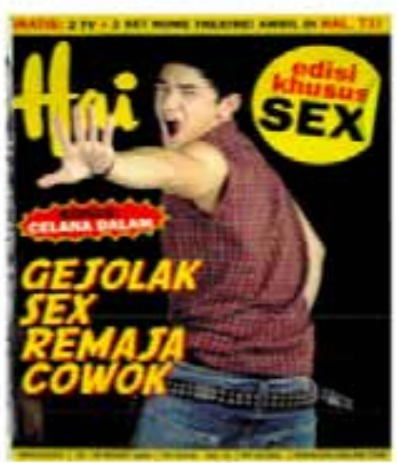

Hai Edisi Seks 2004 
experience) menjadi lebih menyenangkan. Pengalaman menyenangkan diperoleh pembaca saat menunggu kejutan-kejutan erotis ketika membuka halaman-halaman majalah. Melihat sampul adalah bagian dari pengalaman tersebut.

Reichert(2006) lebih lanjut menjelaskan bahwa daya tarik seksual suatu produk bertujuan agar produk laku dijual baik secara langsung maupun tidak langsung. Untuk kasus Hai, sampul majalah menjadi kemasan berdaya tarik seksual agar produknya menarik perhatian calon pembaca untuk membelinya. Usaha ini sekaligus untuk menarik pengiklan agar membayar ruang di majalah tersebut dengan pertimbangan bahwa daya tarik seksual menjadi pendorong remaja untuk membeli dan membaca iklan di dalamnya. Kedua faktor tersebut menunjukkan bahwa komodifikasi seks menjadi jurus mempertahankan pangsa pasar sebagai bagian dari strategi pemasaran majalah Hai.

Merujuk pendekatan ekonomi politik media, media bukan entitas netral dan otonom, begitu pula majalah Hai. Konten lebih ditentukan oleh kekuatan ekonomi dan politik di luar pengelolaan majalah Hai. McNair (1994) menjelaskan beberapa kekuatan, seperti pemilik media, modal, hingga pendapatan media lebih menentukan konten media. Apa yang tertulis, tergambar dan terepresentasikan ditentukan kekuatan-kekuatan tersebut. Menurut Shoemaker dan Reese (1996), faktor-faktor yang mempengaruhi pengambilan keputusan atas konten antara lain faktor organisasi, ekstramedia, dan ideologi.

Faktor organisasi berkaitan dengan struktur organisasi yang mempengaruhi topik seksualitas yang dimuat Hai. Kebijakan internal Hai mengikuti kebijakan redaksional yang dijalankan pendiri dan pemilik PT Kompas Gramedia. Pengaruh Jacob Oetama terhadap perjalanan penerbitan majalah Hai cukup besar. Ia banyak melakukan kontrol. Jika ada konten yang membuatnya tidak berkenan, ia akan memberikan teguran atau memanggil pemimpin redaksi. Strategi penulisan majalah Hai juga mengikuti gaya jurnalisme Jacob
Oetama. Menjadi bagian PT Kompas Gramedia mengakibatkan kerja organisasi majalah Hai, mulai dari bagian redaksi, editor, pemasaran, iklan, dan sirkulasi mengikuti kepentingan sang pemilik.

Kompas identik dengan praktik jurnalisme kepiting yang merujuk pada pers yang bergerak ala kepiting. Istilah ini diberikan oleh Rosihan Anwar. Berdasarkan deskripsi Ignatius Haryanto (2002), kepribadian Kompas adalah: "mencoba melangkah setapak demi setapak untuk mengetes seberapa jauh kekuasaan memberikan toleransi kebebasan pers yang ada. Jika aman, kaki kepiting bisa maju beberapa langkah. Jika kondisi tak memungkinkan kaki kepitingpun bisa mundur beberapa langkah.”

Bagi Jacob Oetama, pers harus berprinsip pada demokrasi dan kebebasan. Caranya adalah mempertimbangkan tingkat perkembangan masyarakat, kultur politik, serta nilai-nilai dasar masyarakat. Untuk itu, pers perlu menahan diri untuk kemudian maju lagi (Wahono dan Purnomo, 2010:139). Wacana seksualitas remaja laki-laki majalah $H a i$ yang mendua merupakan strategi Hai untuk mengambil posisi yang aman, layaknya strategi jurnalisme yang dijalankan Kompas. Berada di antara wacana konservatisme dan liberalisme seksual adalah strategi Hai agar mengakomodasi kepentingan pihak dari luar yang mempengaruhi eksistensi majalah Hai atau faktor ekstramedia. Faktor ekstramedia merupakan faktor-faktor yang berhubungan dengan lingkungan di luar majalah $H a i$, antara lain sumber penghasilan media dan pihak eksternal yang berpengaruh terhadap eksistensi media (Shoemaker dan Reese, 1996).

Untuk bertahan hidup, media melakukan kompromi terhadap kepentingan sumber dayanya. Penghasilan Hai diperoleh dari pelanggan/pembeli dan pengiklan. Wacana seksualitas yang dibangun merupakan kompromi Hai dengan kedua pihak tersebut. Pada tahun 1991 harga Hai dipatok Rp. 2500,00. Jika membeli/berlangganan, harga per bulannya Rp. 10.000,00. Harga tersebut mencerminkan konsumen remaja kalangan menengah ke atas, 
dan relatif lebih tinggi dibandingkan majalah Mode dan Gadis sebagai kompetitor (15 Tahun Majalah Hai, Tumbuh Bersama Pembaca, 1992). Persaingan harga ketiga majalah tersebut berfluktuasi dari tahun ke tahun.
Untuk menghindari konflik dengan orang tua yang berpotensi pada pelarangan orang tua, maka Hai memilih untuk mengakomodasi kepentingan tersebut. Sementara itu untuk tetap mempertahankan pembaca remaja, Hai

Tabel 1: Perbandingan Harga Majalah Gadis, Mode, dan Hai

\begin{tabular}{|l|c|c|c|c|c|c|c|c|c|c|}
\hline \multirow{2}{*}{ Majalah } & \multicolumn{10}{|c|}{ Harga (dalam Rupiah) } \\
\cline { 2 - 11 } & $\mathbf{1 9 9 5}$ & $\mathbf{1 9 9 6}$ & $\mathbf{1 9 9 7}$ & $\mathbf{1 9 9 8}$ & $\mathbf{1 9 9 9}$ & $\mathbf{2 0 0 0}$ & $\mathbf{2 0 0 1}$ & $\mathbf{2 0 0 2}$ & $\mathbf{2 0 0 3}$ & $\mathbf{2 0 0 4}$ \\
\hline Gadis & 2.975 & 2.975 & 4.500 & 6.000 & 6.000 & 6.000 & 8.000 & 9.000 & 10.000 & 12.000 \\
\hline Mode & 3.950 & 3.950 & 4.800 & \multicolumn{8}{|c|}{ Berhenti terbit } \\
\hline Hai & 3.500 & 3.500 & 3.500 & 5.500 & 5.500 & 5.500 & 6.500 & 10.000 & 10.000 & 10.000 \\
\hline
\end{tabular}

Sumber: Majalah Hai, Gadis dan Mode

Harga tersebut adalah harga regular. Pada waktu-waktu tertentu, Hai terbit dengan edisi khusus yang harganya lebih mahal. Misalnya Edisi Alternatif tahun 1996 harganya menjadi Rp. 7.500,00; Edisi Khusus Liburan 1997 berharga Rp. 5.000,00; Tahunan 1998 dengan harga Rp. 10.000; Edisi Khusus Cewek Seksi tahun 2001 dengan harga Rp.15.000; atau Edisi Khusus Seks 2002 dengan harga Rp. 10.000,00.

Dengan harga yang cukup tinggi dan bersaing dengan produk kompetitor, maka Hai menjadi produk yang bergengsi bagi remaja kalangan menengah ke atas sebagai target sasarannya. Remaja pembeli/pelanggan majalah Hai membayar majalah yang dibelinya dengan uang pemberian orang tua. Keterlibatan pihak orang tua sebagai pembuat keputusan dalam berbelanja majalah menyebabkan $\mathrm{Hai}$ mengakomodasi kebutuhan orang tua. Bentuk akomodasi tersebut terefleksikan dalam posisi majalah Hai yang menjembatani kepentingan keduanya.

Pihak orang tua sebagai generasi yang lebih tua menganut pemahaman konservatisme seksual yang memandang moralitas sebagai sesuatu yang penting. Sementara dari pihak remaja, identik dengan generasi anti kemapanan yang menolak norma yang dipegang oleh orang tua. Sebagai generasi hedonis dan konsumtif, remaja lebih banyak menerima terpaan informasi dari media global yang justru mempromosikan gagasan tentang kebebasan seksual. menyampaikan gagasan kebebasan seksual. Wacana seksualitas dalam majalah Hai adalah jalan tengah di antara dua wacana yang dominan sebagai strategi Hai untuk mempertahankan pangsa pasarnya.

Sumber penghasilan lainnya adalah iklan. Iklan membeli ruang yang tersedia dalam majalah dengan mempertimbangkan potensi Hai untuk dibaca banyak orang. Irwan Iskandar dalam majalah Cakram (1992) menyatakan walaupun Hai memiliki positioning yang jelas, ternyata kurang mengundang minat pengiklan.

Situasi ini memprihatinkan untuk majalah Hai yang bertiras 80.000 . Strategi yang dilakukan untuk menarik pengiklan adalah mempertajam segmentasi, antara lain menyesuaikan konten dengan psikografis remaja laki-laki yang berbeda dengan remaja perempuan sehingga produk Hai harus berbeda dengan Gadis.

Tema-tema seks menjadi salah satu strategi Hai yang membedakan selera remaja laki-laki dan perempuan. Asumsi klasik bahwa laki-laki lebih tertarik pada seks dan erotika, sementara perempuan lebih tertarik pada cinta dan romantisme (Clark dan Hatfield, 1989:52) menjadi alasan majalah laki-laki tidak melewatkan pembahasan tentang seks. Logika ini pula yang digunakan $\mathrm{Hai}$.

Strategi tersebut cukup berhasil menaikkan minat pengiklan untuk beriklan di majalah Hai. Komposisi iklan dan konten dalam majalah Hai pada tahun 1991 dan periode 
1995-2004 menunjukkan terjadinya kenaikan jumlah iklan. Penurunan terjadi di tahun 1998 bersamaan dengan terjadinya krisis moneter yang membuat lesunya belanja iklan (Margana, 2000). Penjelasan komposisi tersebut adalah sebagai berikut: seksual menjadi salah satu andalan majalah Hai untuk menarik perhatian pembaca dan pengiklan. Rubrik seksualitas majalah Hai mampu menarik perhatian pengiklan. Dalam halaman yang memuat rubrik seksualitas diisi oleh iklan produk-produk besar, seperti Sony

Tabel 2: Komposisi Konten dan Iklan Majalah Hai

\begin{tabular}{|c|c|c|c|c|c|c|c|c|c|c|c|}
\hline \multirow{2}{*}{ Kategori } & \multicolumn{11}{|c|}{ TAHUN } \\
\hline & 1991 & 1995 & 1996 & 1997 & 1998 & 1999 & 2000 & 2001 & 2002 & 2003 & 2004 \\
\hline Musik & 5 & 9 & 9 & 12 & 10 & 13 & 0 & 4 & 15 & 11 & 8 \\
\hline Film & 0 & 3 & 1 & 2 & 7 & 2 & 0 & 3 & 0 & 1 & 4 \\
\hline Bintang & 5 & 5 & 5 & 5 & 6 & 6 & 10 & 5 & 5 & 2 & 1 \\
\hline TV & 8 & 0 & 0 & 3 & 0 & 0 & 0 & 0 & 0 & 0 & 0 \\
\hline Sport & 1 & 0 & 1 & 8 & 6 & 2 & 0 & 0 & 2 & 0 & 1 \\
\hline Fashion & 1 & 2 & 6 & 1 & 1 & 0 & 0 & 0 & 0 & 0 & 1 \\
\hline Otomotif & 1 & 3 & 3 & 2 & 2 & 0 & 0 & 0 & 0 & 0 & 0 \\
\hline Teknologi & 3 & 0 & 0 & 1 & 1 & 0 & 0 & 0 & 0 & 1 & 0 \\
\hline Petualangan & 1 & 0 & 0 & 0 & 0 & 0 & 0 & 0 & 0 & 0 & 0 \\
\hline Sekolah & 1 & 2 & 3 & 2 & 1 & 0 & 0 & 0 & 0 & 0 & 0 \\
\hline Pendidikan & 0 & 3 & 2 & 0 & 0 & 0 & 0 & 4 & 0 & 0 & 2 \\
\hline Seks & 0 & 2 & 2 & 1 & 1 & 19 & 14 & 3 & 5 & 13 & 12 \\
\hline Psikologi & 1 & 0 & 0 & 0 & 1 & 0 & 0 & 7 & 0 & 0 & 0 \\
\hline Hobi & 1 & 0 & 0 & 1 & 0 & 0 & 0 & 0 & 0 & 0 & 0 \\
\hline Traveling & 0 & 0 & 0 & 0 & 1 & 0 & 0 & 0 & 0 & 0 & 0 \\
\hline Berita Remj & 0 & 0 & 0 & 0 & 1 & 4 & 0 & 2 & 0 & 0 & 0 \\
\hline Opini & 1 & 3 & 1 & 2 & 2 & 0 & 1 & 1 & 3 & 2 & 1 \\
\hline Fiksi & 3 & 2 & 3 & 3 & 1 & 1 & 1 & 0 & 0 & 0 & 0 \\
\hline Wawancara & 1 & 0 & 1 & 1 & 2 & 0 & 0 & 0 & 0 & 1 & 1 \\
\hline Humor & 1 & 1 & 1 & 1 & 1 & 0 & 0 & 0 & 1 & 1 & 1 \\
\hline Resensi & 0 & 4 & 0 & 3 & 4 & 0 & 0 & 0 & 1 & 0 & 2 \\
\hline Surat & 1 & 1 & 1 & 1 & 1 & 1 & 0 & 0 & 0 & 1 & 1 \\
\hline Event & 0 & 5 & 6 & 6 & 5 & 0 & 0 & 0 & 0 & 0 & 2 \\
\hline Kuis & 2 & 1 & 0 & 2 & 0 & 2 & 1 & 0 & 2 & 0 & 0 \\
\hline Prestasi & 1 & 0 & 0 & 0 & 0 & 0 & 0 & 0 & 0 & 0 & 0 \\
\hline Pernik2 & 1 & 0 & 0 & 0 & 1 & 0 & 0 & 0 & 0 & 0 & 0 \\
\hline Kartun & 0 & 0 & 0 & 0 & 0 & 0 & 1 & 1 & 1 & 2 & 1 \\
\hline Games & 0 & 0 & 0 & 1 & 1 & 3 & 0 & 0 & 0 & 0 & 1 \\
\hline Iklan & 5 & 26 & 33 & 27 & 10 & 28 & 23 & 28 & 23 & 16 & 33 \\
\hline Jumlah & 44 & 72 & 78 & 85 & \begin{tabular}{|l|}
66 \\
\end{tabular} & 81 & 51 & 58 & 58 & 51 & 72 \\
\hline Iklan (\%) & 11.36 & 36.11 & 42.31 & 31.76 & 15.15 & 34.57 & 45.10 & 48.28 & 39.66 & 31.37 & 45.83 \\
\hline Harga (Rp) & 1.750 & 3.500 & 3.500 & 3.500 & 4.500 & 5.500 & 8.500 & 8.500 & 12.000 & 12.000 & 20.000 \\
\hline
\end{tabular}

Sumber: Hai edisi 8/1/1991, 14/11/1995, 15/10/1996, 18/11/1997, 24/2/1998, 3/9/1999, 25/7/2000, $12 / 2 / 2001,4 / 3 / 2002,3 / 3 / 2002,22 / 3 / 2004$

Untuk mendatangkan iklan, Hai harus mampu menjangkau pembaca, dan konten
Ericsson, Levi's, bahkan Axe dan Green Sands menjadi sponsor tetap dalam jangka waktu yang 


\section{Gambar 5 \\ Hai edisi 6/10/2000}

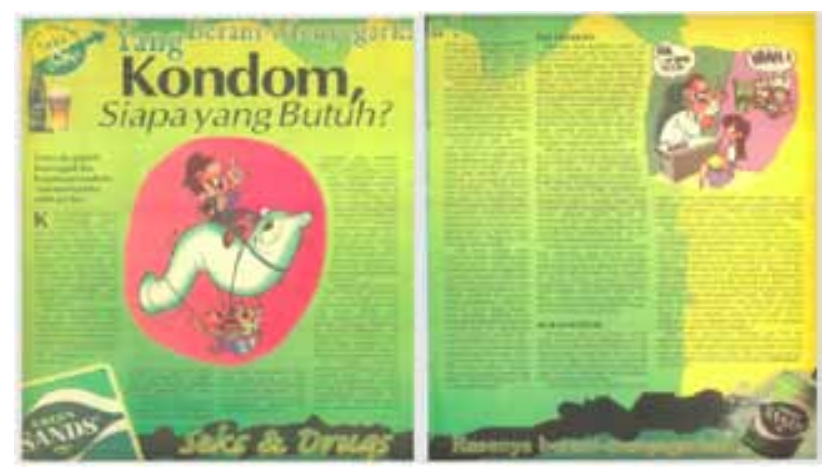

Gambar 6

Hai edisi 16/4/2001

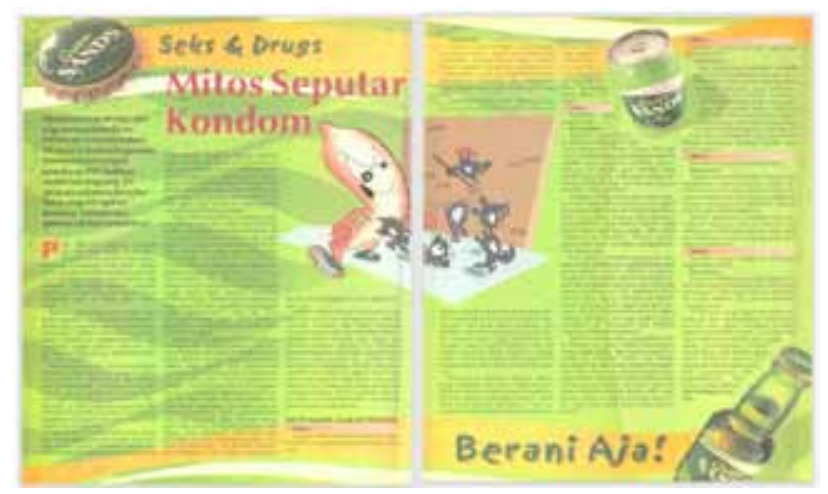

Gambar 7

Hai edisi 23/7/1999

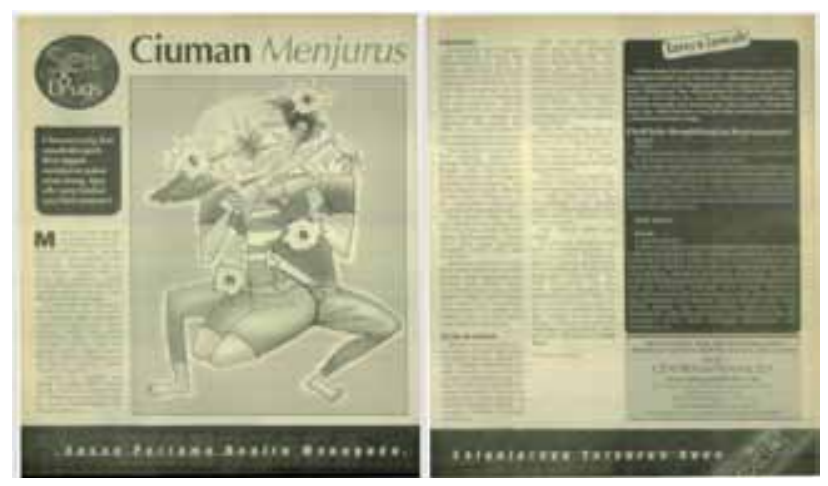

cukup lama.

Adanya iklan produk global di rubrik seksualitas mendorong Hai memasukkan isu seksual global dalam diskusi seksualitas, misalnya tentang kondom. Hai pro-kondom mengikuti wacana global tentang kesadaran bahaya HIV/AIDS. Hal itu dibahas dalam tulisan yang disponsori Green Sands dan ber-tagline Rasanya Berani Menyegarkan. Menyatakan diri sebagai institusi pro-kondom adalah langkah berani Hai ketika wacana konservatisme seksual yang melarang seks bebas masih dominan di Indonesia. Kata "berani" menjadi label yang dilekatkan pada remaja pro-kondom.

Tahun 2001, tagline berubah menjadi Berani Aja!. Kata "berani" dipertahankan dan lebih eksplisit. Jika sebelumnya mengacu pada rasa minuman, maka di tagline terbaru maknanya lebih luas. Masih tentang kondom, tulisan ini menjelaskan hal yang sama dan mendorong remaja berani bersikap pro-kondom dengan meluruskan mitos-mitos menyesatkan tentang kondom.

Hal yang sama terdapat dalam rubrik seksualitas yang disponsori Axe. Axe dengan tagline Kesan Pertama Begitu Menggoda, Selanjutnya Terserah Anda, memiliki hubungan yang kuat dengan tulisan di rubrik tersebut. Tulisan tersebut menjelaskan bahwa berciuman adalah hal yang wajar namun beresiko karena bisa memicu terjadinya hubungan seksual. Selanjutnya $\mathrm{Hai}$ menyerahkan keputusan pembaca apakah memutuskan untuk melakukan aktivitas berciuman atau tidak dengan mempertimbangkan norma-norma yang dipegang oleh masyarakat.

Menurut Giddens (1991:196), konsumsi komoditas yang diproduksi oleh industri kapitalis merupakan bagian dari upaya untuk mengekspresikan diri. Modernitas membuka ruang bagi proyeksi diri (project of the self), di mana individu membentuk identitas dirinya dengan mengacu pada standar tertentu yang dikondisikan oleh komoditas yang diproduksi oleh industri kapitalis.

Dalam majalah Hai memang tidak ditemukan iklan produk-produk seksual, seperti kondom, obat perangsang seksual, layanan telepon seks dan sejenisnya mengingat pembacanya adalah remaja. Namun demikian, pengiklan cenderung membeli ruang di media yang memiliki kepentingan yang sama dengan misi dan visi produknya. Produk industri kapitalis ditujukan bagi masyarakat moderen atau post-traditional (Giddens, 1991) yang salah satu indikatornya adalah masyarakat yang 
otonom dalam membentuk identitas dirinya. Individu tidak lagi hanya mengacu pada standar norma, namun ia menyesuaikan dengan apa yang diinginkan dan dibutuhkannya.

Model jalan tengah dalam membangun wacana seksualitas merupakan politik dua kaki majalah Hai untuk mengakomodasi kepentingan-kepentingan yang mempengaruhi eksistensi majalah Hai dalam bisnis media cetak. Strategi mengakomodasi berbagai kepentingan ini menjadi andalan Jacob Oetama untuk mempertahankan Kompas sehingga mampu menjadi surat kabar yang cukup terkemuka di mata pembaca dan pengiklan. Pengalaman Kompas ketika mengalami dua kali pembredelan pada tahun 1965 dan 1978 mendorongnya untuk menerapkan prinsip hati-hati.

Kompas mengambil jalur pasar yang pragmatis dengan bersikap hati-hati untuk urusan politik dan menegaskan keberpihakannya pada kelas menengah sekuler (dalam Hill, 2011:37). Keberpihakan Kompas pada pemerintah Orde Baru disindir oleh Ben Anderson sebagai "Koran Orba Sejati" karena memiliki gaya penulisan yang sarat 'kebosanan tak terperikan' akibat kehati-hatiannya dalam menulis masalah politik yang sensitif (Hill, 2011:51).

Jacob Oetama tidak hanya berhatihati dengan pemerintah, namun juga dengan kepentingan kelompok masyarakat yang berpotensi mengancam eksistensi media yang berada di dalam kerajaan bisnisnya. Jacob Oetama tidak segan mencabut izin penerbitan media di dalam jajaran penerbitannya, misalnya kasus tabloid Monitor dan Senang.

Beberapa kasus tersebut menunjukkan bahwa Jacob Oetama memiliki posisi tidak tertandingi di PT Kompas Gramedia, dan menjadi sosok yang menghindari kontroversi dan konflik demi mengamankan imperium bisnisnya. Kebijakan Jacob Oetama berhasil membawa Kompas menempati posisi terdepan perolehan iklan cetak terbanyak di Indonesia dan membuatnya menjadi konglomerat ternama (dalam Hill, 2011: 99).

Belajar dari kasus Kompas dan mediamedia lain di bawah bendera PT Kompas Gramedia, dalam menampilkan konten seksualitas, Hai mengikuti pedoman yang digariskan oleh pemerintah. Salah satunya adalah menghindari unsur-unsur pornografi. Untuk memahami batasan pornografi yang dimaksud pemerintah antara lain merujuk UU Film No 8/1992. Pornografi adalah: adegan yang menggambarkan laki-laki dan perempuan yang menunjukkan ketelanjangan; menampilkan alat kelamin, paha, payudara, pantat, atau tanpa busana; adegan ciuman yang membangkitkan hasrat antara pasangan heteroseksual maupun homoseksual; adegan persenggamaan antara manusia atau hewan baik berupa gerakan, suara maupun tindakan; atau tindakan masturbasi, lesbian, homoseksual atau seks oral (Paramadita, 2012:77).

Untuk itu Hai menyiasatinya lewat ilustrasi kartun yang menggambarkan orang berciuman atau tubuh telanjang, dengan muatan humor:

\section{Gambar 8}

Gambar remaja berciuman dan laki-laki dan perempuan yang telanjang dalam Hai edisi 5/1/2004 dan 3/9/1999
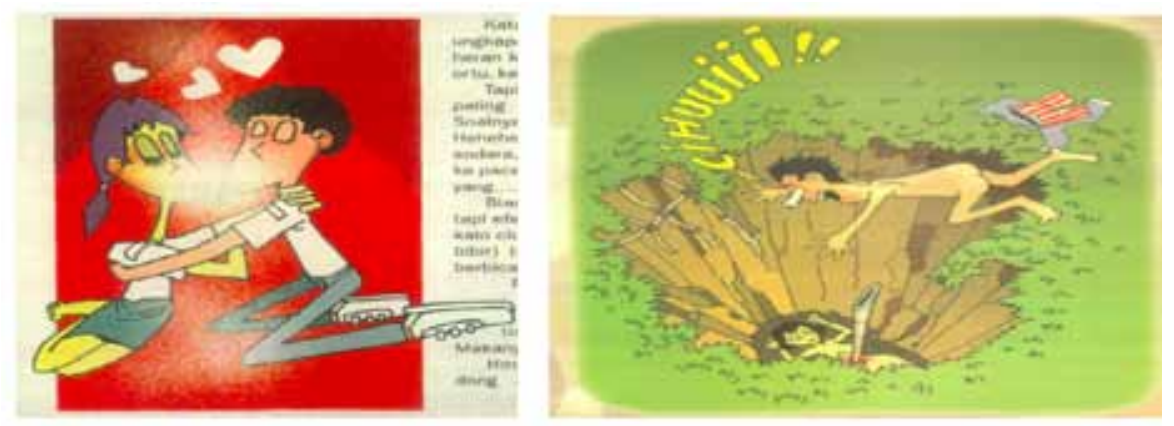
Selain gambar kartun, Hai juga memanfaatkan simbol-simbol tertentu untuk mengilustrasikan objek-objek yang mengandung unsur pornografi, seperti alat kelamin sebagai personifikasi. Contoh ilustrasi-ilustrasi tersebut adalah:
Islam di bulan puasa. Hal ini menarik mengingat sejarah PT Kompas Gramedia yang identik dengan afiliasi media ini pada partai Katolik dan didirikan sejumlah jurnalis Katolik keturunan Tionghoa dan Jawa (Hill, 2011:97).

Akomodasi $\mathrm{Hai}$ pada nilai-nilai Islam

Gambar 9

Personifikasi Penis dalam Hai edisi 12/8/2002

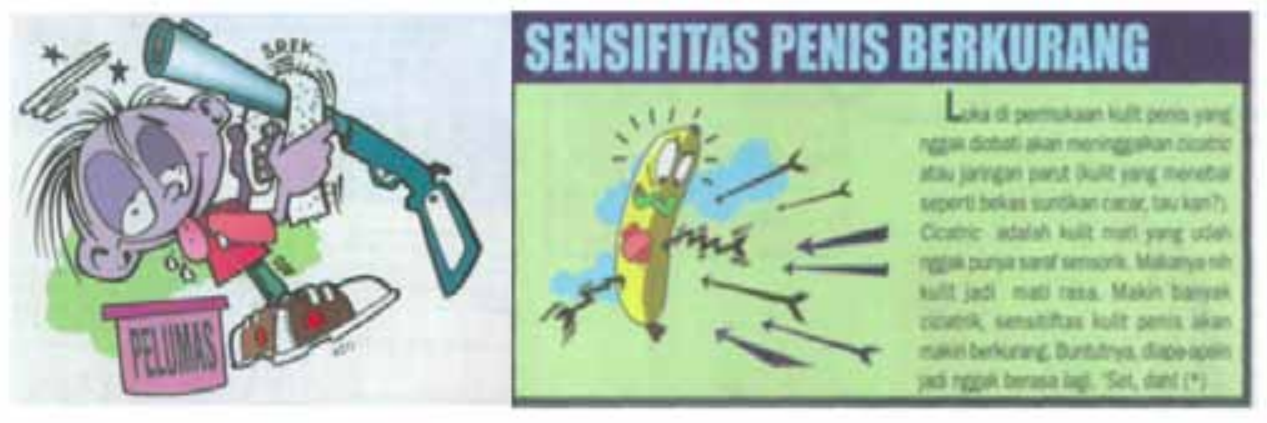

Di saat yang sama kelompok-kelompok masyarakat berbasis gender, etnis dan agama yang termarginal di masa Orde Baru mulai tampil dan memiliki pengaruh yang cukup penting, misalnya kelompok-kelompok Islam. Pada masa pemerintahan pasca Suharto berlangsung proses Islamisasi dengan pola yang kompleks. Muncul kelompok-kelompok Islam yang klasifikasi ideologinya tidak lagi hanya berdasarkan kategori modernis dan tradisionalis, namun terpecah lagi dengan munculnya kategori baru, yaitu liberal dan militan (Van Wichelen, 2007:96).

Berkembangnya Islam di periode pasca Orde Baru diikuti diadopsinya Islam sebagai way of life oleh masyarakat. Munculnya kelompok-kelompok Islam yang diikuti oleh adopsi nilai-nilai Islam memunculkan kembali upaya untuk kembali pada wacana seksualitas yang berdasarkan pada norma-norma sosial, kesusilaan, dan agama. Kepanikan moral akibat maraknya konten seksual di media massa turut menjadi pemicu upaya tersebut. Tuntutan untuk mengembalikan nilai dan norma Islam sebagai pedoman hidup banyak disuarakan.

Sebagai adaptasi pada lingkungan eksternal, Hai memasukkan wacana-wacana agama dalam diskusi seksualitasnya. Misalnya pembahasan seksualitas lewat sudut pandang juga didorong oleh munculnya pasar muslim pasca Orde Baru, yang ditandai oleh beredarnya produk-produk berlabel Islam, mulai fashion dan hijab style, kosmetik halal, film atau musik religi, wisata syariah dan sebagainya. Fenomena budaya konsumsi Islam yang berlangsung ikut mempengaruhi konten Hai. Kebutuhan pasar dan eksistensi mendorong Hai menyesuaikan dirinya dengan nilai-nilai Islam sebagai materi penerbitannya.

Era reformasi yang identik dengan era keterbukaan mendorong bermunculannya paham-paham yang terpinggirkan pada masa sebelumnya, seperti paham kesetaraan gender. Persoalan kesetaraan gender tidak hanya tentang persamaan hak antara laki-laki dan perempuan, namun juga hak kelompok Lesbian, Gay, Biseksual dan Transgender (LGBT). Wacana kesetaraan gender terlihat pada topik-topik tentang hak menjaga virginitas yang tidak hanya berlaku bagi perempuan namun juga laki-laki, atau wacana tentang laki-laki gentleman yang menghargai perempuan.

Begitu juga tentang persoalan LGBT, walaupun sesungguhnya Hai pro heteroseksual, namun Hai mulai mengajak pembacanya untuk menerima kelompok LGBT. Misalnya dengan menjadikan Dede Oetomo selaku akademikus 
sekaligus aktivis gay dalam sub-artikel berjudul "Jangan Takut Sama Gay" (18/3/2002).

Ideologi mempengarui media dalam menyampaikan realitas kepada audiens. Faktor ideologi ini menjelaskan ideologi apa yang dipercaya oleh Hai ketika menjelaskan seksualitas yang itu tercermin dalam artikel dan rubrik seksualitas. Ideologi yang dimaksud Shoemaker dan Reese (1996:213) merujuk pada definisi ideologi yang diutarakan Raymond Williams (1977) dan Samuel Becker (1984). Menurut Williams, ideologi merupakan sistem makna, nilai, dan kepercayaan yang terartikulasi dan formal yang diabstraksikan sebagai pandangan dunia atau pandangan kelas. Sedangkan Becker menjelaskan bahwa ideologi menentukan cara individu melihat dunia dan diri mereka sendiri sehingga mengontrol apa yang dilihat individu adalah hal yang normal dan jelas.

Pemahaman Hai atas seksualitas tidak terlepas dari ide tentang hegemonic male sexuality, yaitu ide yang mempercayai dominasi dan kekuatan laki-laki secara seksual. Gagasan ini meyakini bahwa standar seksualitas lakilaki ditentukan oleh penisnya baik secara fisik maupun simbolis. Ukuran dan kemampuan ereksi menjadi sesuatu yang penting bagi lakilaki (Plummer, 2005).

Hai merepresentasikan laki-laki sebagai inisiator perilaku seksual. Dominasi lakilaki dalam relasi seksual dengan perempuan diwujudkan secara fisik lewat konstruksi atas kejantanan yang indikatornya adalah kualitas organ reproduksi, termasuk penis yang mendukung kesuburannya. Laki-laki adalah pelaku seksual aktif yang memiliki hasrat seksual dan fantasi liar. Tidak hanya secara fisik, dominasi laki-laki juga ditunjukkan lewat posisi perempuan yang dikontrakan sebagai controller (Kimmel, 2005:5). Akibat peran seksualnya, maka laki-laki berupaya meningkatkan performa seksualnya lewat konstruksi kejantanan tersebut.

Promosi anti homoseksual dalam rubrik dan artikel seksualitas majalah Hai merupakan sebuah homophobia. Menurut Leverenz (1991) anti homoseksual merupakan ketakutan laki- laki dianggap gay sehingga laki-laki akan selalu menunjukkan ketertarikan seksualnya pada perempuan (dalam Kimmel, 2005:35). Ini merupakan bentuk lain dari hegemonic male sexuality yang melihat superioritas lakilaki adalah berdasarkan kemampuannya dalam menundukkan perempuan. Konstruksi Hai atas seksualitas laki-laki menunjukkan bahwa wacana seksualitas yang dipahami Hai dipengaruhi oleh sistem norma heteroseksual dan ideologi patriarki. Norma heteroseksual membedakan laki-laki dan perempuan dalam relasi tertentu secara tegas berdasarkan pada ideologi patriarki yang memberikan legitimasi atas superioritas laki-laki. Kerangka pemahaman inilah yang menjadi tuntunan bagi Hai dalam menjelaskan seksualitas.

\section{Simpulan}

Pemaparan di atas menunjukkan bahwa pendidikan seks menjadi ruang Hai untuk mendiskusikan seksualitas. Pendidikan seks mempromosikan seks yang aman sehingga menghasilkan ambiguitas wacana seksualitas. Konstruksi tersebut didukung oleh ketiga faktor yang telah dijabarkan, yaitu organisasi, ekstramedia, dan ideologi. Kondisi inilah yang dijelaskan lewat pendekatan ekonomi politik media yang tidak semata-mata melihat kepentingan media hanya pada kekuatan ekonomi. Media adalah situs di mana berbagai kepentingan saling bertarung.

Ambiguitas wacana seksualitas remaja laki-laki mempromosikan seks yang sehat. Kepentingan Hai mempromosikan seks yang sehat adalah untuk mempertahankan eksistensinya secara ekonomi, politik dan sosial. Eksis secara ekonomi berarti tetap bertahan di kalangan pembaca dan pengiklan; secara politik berarti menjaga hubungan harmonis dengan pemerintah; secara sosial berarti tidak menimbulkan keresahan di masyarakat. Dengan demikian, konsep seks yang sehat (safe sex) dijalankan dalam rangka mengamankan posisi Hai (safe positioning). 
Daftar Pustaka

Anugrah, Insan Praditya. (2014). Majalah Playboy: Bentuk Awal Komodifikasi Kebebasan Seks Dalam Industri Media, History Inc. (http://blog.history-inc. com/2014/01/majalah-playboy-bentukawal.html, diakses tanggal 30 April 2015)

Clark, Russel D dan Hatfield, E. (1989). Gender Differences and Receptivity to Sexual Offers, Journal of Psychology and Human Sexuality, 2(1)

Giddens, Anthony. (1991). Modernity and Self Identity: Self and Society in the Late Modern Age, California: Stanford University Press

Haryanto, Ignatius. (2002). Jurnalisme Kepiting, Pantau 3 Juni 2002

Hill, David T. (2011). Pers Di Masa Orde Baru, Jakarta: Yayasan Pustaka Obor Indonesia

Iqani, Mehita. (2012). Consumer Culture and the Media: Magazines in the Public Eye, New York: Pallgrave Macmillan

Kimmel, Michael S. (2005). Gender of Desire: Essays on Male Sexuality, Albany: State University of New York Press Margana, A. (2000). Strategi Manajemen Bisnis Media Cetak Menghadapi Persaingan Bebas. Makalah disampaikan pada Pendidikan Jumalistik Mahasiswa Tingkat Pengelola seIndonesia di Universitas Lampung, Bandarlampung

McNair, Brian. (1994). News and Journalism in the UK: A Textbook, London and New York: Routledge Mosco, Vincent. (2009). The Political Economy of Communication, London: Sage Publication Paramadhita, Intan. (2012). "Cinema, Sexuality and Censorship in Post-Suharto Indonesia”. Dalam Tilman Baumgartel, Southeast Asian Independent Cinema, Hongkong: Hongkong University Press Plummer, Ken. (2005). "Male Sexualities". Dalam Michael S Kimmel, Jeff Hearn, dan R. W. Connel, Handbook of Studies on Men and Masculinities,
California: $\quad$ Sage Publications

Reichert, T dan Lambiase. (2006). "Peddling Desire: Sex and the Marketing of Media and Consumer Goods". Dalam T. Reichert, Sex in Consumer Culture: The Erotic Content of The Media and Marketing, New York: Routledge

Wertime, Kent. (2003). Building Brands and Believers: Membangun Merek dan Pengikutnya, Jakarta: Erlangga

Shimp, Terence A. (2003). Periklanan Promosi Aspek Tambahan Komunikasi Terpadu, Jakarta: Erlangga Shoemaker, Pamela J dan Reese, Stephen D.. (1996). Mediating The Message:Theories of Influences on Mass Media Content, USA: Longmann publisher Wahono, Satrio dan Purnomo, D. (2010). Animal-Based Management: Rahasia Merek-Merek Raksasa Berjaya, Jakarta: PT Gramedia Pustaka Utama. Van Wichelen, Sonja. (2007). "Reconstructing 'Muslimnes': New Bodies in Urban Indonesia". Dalam Cara Aithison, Peter Hopkins, dan Mei-PoKwan, Geographies of Muslim Identities: Diaspora, Gender, and Belonging, England: Ashgate "15 Tahun Majalah Hai, Tumbuh Bersama Pembaca", dalam Cakram, Februari 1992/96 